\title{
DETERMINATION OF PESTICIDES IN RIVER SURFACE WATERS OF CENTRAL CHILE USING SPE-GC-MS MULTI-RESIDUE METHOD
}

\author{
MARÍA JOSÉ CLIMENT ${ }^{1,2 *}$, MARÍA JESÚS SÁNCHEZ-MARTÍN ${ }^{3}$, MARÍA SONIA RODRÍGUEZ-CRUZ \\ PABLO PEDREROS ${ }^{1,2}$, ROBERTO URRUTIA ${ }^{1,2}$ AND ELISEO HERRERO-HERNÁNDEZ ${ }^{3}$
}

${ }^{\prime}$ Environmental Sciences Faculty \& EULA Center, Universidad de Concepción, Barrio Universitario s/n, 4030000 Concepción, Chile. ${ }^{2}$ Center for Water Resources for Agriculture and Mining (CRHIAM), Universidad de Concepción, Victoria 1295, 4030000 Concepción, Chile

${ }^{3}$ Institute of Natural Resources and Agrobiology of Salamanca, IRNASA-CSIC, c/ Cordel de Merinas, 40-52, 37008 Salamanca, España

\begin{abstract}
In areas with agricultural activity, the excessive use of pesticides can contaminate water resources. That is why a multi-residue method based on solid-phase extraction (SPE) and gas chromatography analysis coupled to mass spectrometry (GS-MS) was used to determine eleven pesticides and five degradation products in surface water of Central Chile. The parameters that can affect the efficiency of the SPE process were optimized considering the information available in bibliography. As in other studies, the best results were obtained when $500 \mathrm{~mL}$ of water was pre-concentrated using Oasis HLB polymer cartridges and acetone and acetonitrile were used as solvents for the elution. To ensure good quantification, matrix-matched standards were used, providing good linearity in the studied concentration range $\left(0.10-1.5 \mu \mathrm{g} \mathrm{L}^{-1}\right)$, with recovery percentages $>60 \%$, precisions $<19 \%$ and quantification limits $<0.1 \mu \mathrm{g} \mathrm{L} \mathrm{L}^{-1}$. The surface water samples were collected at the end of summer and winter seasons, considering rivers, creeks and irrigation canals of Cachapoal River basin. A percentage $>87 \%$ of the pesticides analyzed in this research were detected in more than one sampled site in both seasons. The most ubiquitous compounds were desethylterbuthylazine (DET), pyrimethanil, cyprodinil and diazinon, and the compounds detected in highest concentration were simazine and degradation products derived from triazines. Las Cabras and Tahuilla irrigation canals presented the highest concentrations of pesticides. Significant differences were found in the total concentration of pesticides for sites sampled at the end of the summer and winter season.
\end{abstract}

Key words: agricultural activity, degradation products, pesticides, water pollution.

\section{INTRODUCTION}

Pesticides are chemical compounds that are applied to the environment to eliminate plant and animal pests and thus avoid the destruction of 50-60\% of world food production. However, the intensive use of these compounds can cause severe environmental pollution problems since they are distributed among water, soil, air and biota, affecting ecosystem biodiversity [1-2] and human health [3]. Pesticides can reach a body of water through drift during application, runoff, leaching toward the water table and washing of receptacles of machines after application [4]. Once in this medium, they can be partially or totally degraded, remain unchanged, be deposited in the sediment of rivers and lakes, become bioconcentrated in aquatic organisms or return to the atmosphere through volatilization [5]

Studies carried out in Asia [6], Europe [7-8] and the USA [9] show that pesticides and their degradation products are often detected in surface water, in some cases at levels exceeding the maximum individual limit $(0.1 \mu \mathrm{g}$ $\mathrm{L}^{-1}$ ) established by the European Commission (EC) for drinking water [10]. Therefore, various countries around the world have developed monitoring programs to evaluate the level of pesticide contamination in bodies of water, taking the measures necessary to minimize the impact of these substances on the environment and protect the quality of water resources [11].

In Latin America, studies on water contamination by pesticides is a littledeveloped area; however, some studies have been done in Mexico, Nicaragua, Costa Rica, Brazil and Argentina, in which it was shown that bodies of water adjacent to agricultural areas can present elevated levels of pesticide contamination. For example, research done in Brazil shows that drinking water, surface water and groundwater in areas planted with cotton and sugar cane crops contain diuron, atrazine, simazine, ametryn and metribuzin in concentrations that exceed the maximum individual limit established by the EC [12]. Similarly, in Argentina it has been found that bodies of water adjacent to tobacco, onion, yerba mate, corn or soybean fields or orchards [13] present atrazine and terbuthylazine concentrations over the maximum limit established by the EC $\left(0.1 \mu \mathrm{g} \mathrm{L}^{-1}\right)$.

Although there are few studies related to water contamination by pesticides in Chile, the research carried out to date shows the presence of agrochemicals in the surface water of agricultural areas of the central zone of the country. A study published by Retamal, et al. [14] evaluated the presence of nine pesticides in the water of Maipo River (Central Chile), finding seven compounds at concentrations below $0.1 \mu \mathrm{g} \mathrm{L}^{-1}$. The most recent work, published by Montory, et al. [15], determined the concentration of nineteen organochlorine pesticides (OCPs) in the Nuble River (Central Chile), indicating that lindane and endosulfan were the main compounds detected in surface water and that the total concentration of OCPs reached a maximum level of $26.28 \mathrm{ng} \mathrm{L}^{-1}$.

The drinking water quality standard in Chile (NCh 409/1 of 1984) [16] establishes the maximum individual limit for twelve pesticides, with concentrations that fluctuate between 100 and $0.01 \mu \mathrm{g} \mathrm{L}^{-1}$ for 2,4-D and hexachlorobenzene, respectively. More than four hundred and fifty active substances are currently used for pest control in the country; therefore, it is crucial to evaluate the level of water resource contamination in Chile, mainly in regions with the greatest sales and use of agrochemicals. In order to achieve this it is first necessary to implement a robust analysis method for rapid and simultaneous determination of various types of herbicides, fungicides and insecticides in water samples that allow them to be evaluated with greater certainty.

In general, the determination of pesticides in water is a laborious process, in which the sample taking and pretreatment stages require up to two thirds of the time necessary for the complete analysis [17]. Solid-phase extraction (SPE) as a pretreatment technique is one of the most used for the analysis of organic contaminants in aqueous samples and gas chromatography coupled to a mass spectrometry detector (GC-MS) is one of the most used techniques for evaluating the presence of these contaminants in the environment [18]. In the case of aqueous samples, various studies have used GC-MS to simultaneously determine organochlorine, organophosphorus, triazine and pyrethroid pesticides [19] with detection limits below $0.1 \mu \mathrm{g} \mathrm{L}^{-1}$ and good sensitivity and peak resolution.

The objective of this work was to assess the changes in the presence of sixteen pesticides in river water samples in summer and winter periods in a basin in Central Chile with intense agricultural activity (that of the Cachapoal River). Rainfall is very important in this area because they are intense and short-lived, concentrating between May and August with a monthly average of $68 \mathrm{~mm}$. The compounds determined were four fungicides (pyrimethanil, metalaxyl, cyprodinil, kresoxim-methyl), five herbicides (simazine, fluometuron, atrazine, terbuthylazine, acetochlor), two insecticides (chlorpyrifos, diazinon) and five of their main degradation products [deisopropylatrazine (DIA), deethylatrazine (DEA), desethylterbuthylazine (DET), diazoxon, CGA-92370]. They were selected according to their use in the area in cultivation of fruit trees and the annual report of pesticide sales published by Servicio Agrícola y Ganadero de Chile [20]. A multi-residue method through SPE and subsequent separation and quantification by GC-MS was proposed for determining pesticides [2122] and the levels established by European Commission for drinking water were considered as a reference to determine contamination in the natural water samples from Central Chile. 


\section{EXPERIMENTAL}

Chemicals and reagents

The pesticide standards with purity $>98 \%$ were provided by Sigma-Aldrich (Gillingham, UK) and Dr. Ehrenstorfer (Augsburg, Germany). Selected characteristics of compounds are included in Table 1. A concentration of 500 or $1000 \mu \mathrm{g} \mathrm{mL}^{-1}$ solution was initially prepared in methanol for each standard and then solutions with all of the analytes were prepared at lower concentrations in order to prepare the calibration curves and spike the ultra-high quality (UHQ) or uncontaminated river water samples to evaluate the matrix effect.

Table 1: Common names, uses and physicochemical properties of pesticides selected and some degradation products. All data were taken from ${ }^{(1)}$ EpiSuite Program V. 4.1 and Lewis, et al. [23]. Compounds with letters in brackets correspond to the degradation products of the parent compound with the same letter in the superscript.

\begin{tabular}{|c|c|c|c|c|c|}
\hline Fluometuron & Herbicide & Phenylurea & 111 & $154.3^{(1)}$ & 2.28 \\
\hline DIA (b) & Degradation product & Degradation product & 980 & 130 & 1.15 \\
\hline $\operatorname{DEA}(\mathrm{c})$ & Degradation product & Degradation product & 2700 & 110 & 1.51 \\
\hline Diazoxon (e) & Degradation product & Degradation product & $245.1^{(1)}$ & $174.7^{(1)}$ & $2.10^{(1)}$ \\
\hline Metalaxyl (a) $^{2}$ & Fungicide & Acylalanine & 8400 & 162 & 1.75 \\
\hline Simazine $^{(b)}$ & Herbicide & Triazine & 5.0 & 130 & 2.3 \\
\hline Atrazine $^{(\mathrm{b}, \mathrm{c})}$ & Herbicide & Triazine & 35 & 100 & 2.7 \\
\hline Pyrimethanil & Fungicide & Anilinopyrimidine & 121 & $709.9^{(1)}$ & 2.84 \\
\hline Acetochlor & Herbicide & Chloroacetamide & 282 & 14 & 4.14 \\
\hline Chlorpyrifos & Insecticide & Organophosphate & 1.05 & $415.1^{(1)}$ & 4.7 \\
\hline Cyprodinil & Fungicide & Anilinopyrimidine & 13 & $3111^{(1)}$ & 4.0 \\
\hline Kresoxim-methyl & Fungicide & Strobilurin & 2 & $625.3^{(1)}$ & 3.4 \\
\hline
\end{tabular}

Sw: Water Solubility at $20^{\circ} \mathrm{C}$

log Kow: Octanol-water partitioning coefficient at $\mathrm{pH} 7,20^{\circ} \mathrm{C}$

Koc: Soil sorption coefficient

-: no data available

\section{River water sampling}

During 2016 surface water samples were collected at various points in the Cachapoal River basin in Central Chile (located in the region with the greatest pesticide sales in the country), comprising two rivers (Claro and Cachapoal), two creeks (La Cadena and Zamorano) and two irrigation canals (Las Cabras and Tahuilla). This region has an area of $6370 \mathrm{~km}^{2}$ and the main crops are grapes, apples, peaches, plums, cherries, nectarines, pears, oranges, walnuts, avocados and lemons (Figure 1). Two samplings were carried out, one at the end of the summer (April) and the other in winter season (July), with a total of thirty water samples collected (eighteen in April and twelve in July). The samples were taken in 2-L amber glass bottles and transported to the laboratory in coolers with ice. In less than 48 hours, they were passed through nitrocellulose filters with a pore size of $0.45 \mu \mathrm{m}$ and stored at $-20^{\circ} \mathrm{C}$ until their pre-concentration by SPE.

\section{Analytical methodology and GC-MS chromatographic conditions}

The effects of sorbent type, the solvent used in the elution and preconcentrated sample volume were previously evaluated to optimize the preconcentration process by SPE. Five SPE sorbents for extracting the compounds of interest were compared Oasis HLB (60 mg, Waters), LiChrolut EN (200 mg, Merck), Strata X (60 mg, Phenomenex), silica C18 (Sep-Pak Plus 900 mg, Waters) and carbon (SampliQ $500 \mathrm{mg}$, Agilent)). The procedure was followed as indicated by Herrero-Hernández, et al. [21]. In brief, they were conditioned with $10 \mathrm{~mL}$ of methanol and $10 \mathrm{~mL}$ of UHQ water and a volume of $100 \mathrm{~mL}$ of UHQ water spiked with all of the analytes at a concentration of $1 \mu \mathrm{g} \mathrm{L}^{-1}$ was concentrated. The elution was carried out with $8 \mathrm{~mL}$ of eluent, which was subsequently evaporated to dryness under a nitrogen stream in an EVA-EC2-L evaporator (VLM GmbH, Bielefeld, Germany). The residue was redissolved in

$1.0 \mathrm{~mL}$ of methanol and the extract was filtered with $0.45 \mu \mathrm{m}$ GHP Acrodisc filters for subsequent analysis by GC-MS. The effects of five organic solvents (acetone, acetonitrile, methanol, hexane, ethyl acetate and a combination of acetone and acetonitrile) as eluents and five spiked UHQ water volumes (50, $100,250,500$ and $1000 \mathrm{~mL}$ ) were also assessed.

The analysis was carried out in an Agilent 7890 gas chromatograph coupled to an Agilent 5975C Triple Axis MSD mass spectrometer and the separation was done using a ZB-5MS capillary column (Phenomenex) (30 m x $0.25 \mathrm{~mm}$ id with $0.25 \mu \mathrm{m}$ film thickness). The chromatographic conditions that allowed good separation and quantification of the analytes were as it is indicated by Herrero-Hernández, et al. [21]. The total analysis time was thirty minutes. To identify each pesticide and degradation product, the three most abundant ions were selected by separately injecting each compound and, for quantification, the ion found in the greatest proportion was selected

\section{Analytical method validation}

The different analytic parameters were assessed using samples of UHQ water or uncontaminated natural water spiked with known concentrations of the different compounds. The matrix effect was evaluated in duplicate by comparing the analyte signal obtained when pre-concentrating $500 \mathrm{~mL}$ of UHQ water with that obtained when pre-concentrating $500 \mathrm{~mL}$ of river water, both spiked with a concentration of $0.1 \mu \mathrm{g} \mathrm{L}{ }^{-1}$ of all compounds. The linearity of the calibration curves was evaluated at a concentration range between 0.1 and $1.5 \mu \mathrm{g} \mathrm{L}^{-1}$ using calibration standards prepared in uncontaminated river water (matrix-matched calibration standards) to ensure good quantification. Calculations were made using peak areas. The accuracy (average recovery) was determined by evaluating the recovery percentage for five replicates and precision of the method (repeatability and reproducibility) was assessed by 
determining the concentration, on the same day, of five samples of river water $(500 \mathrm{~mL})$ spiked with $0.1 \mu \mathrm{g} \mathrm{L}^{-1}$ of each compound, as well as the concentration variation of each analyte, for the same sample, for five days. The limits of detection (LODs) and quantification (LOQs) were estimated as the analyte concentration with a signal-to-noise-ratio of 3 and 10 , respectively.

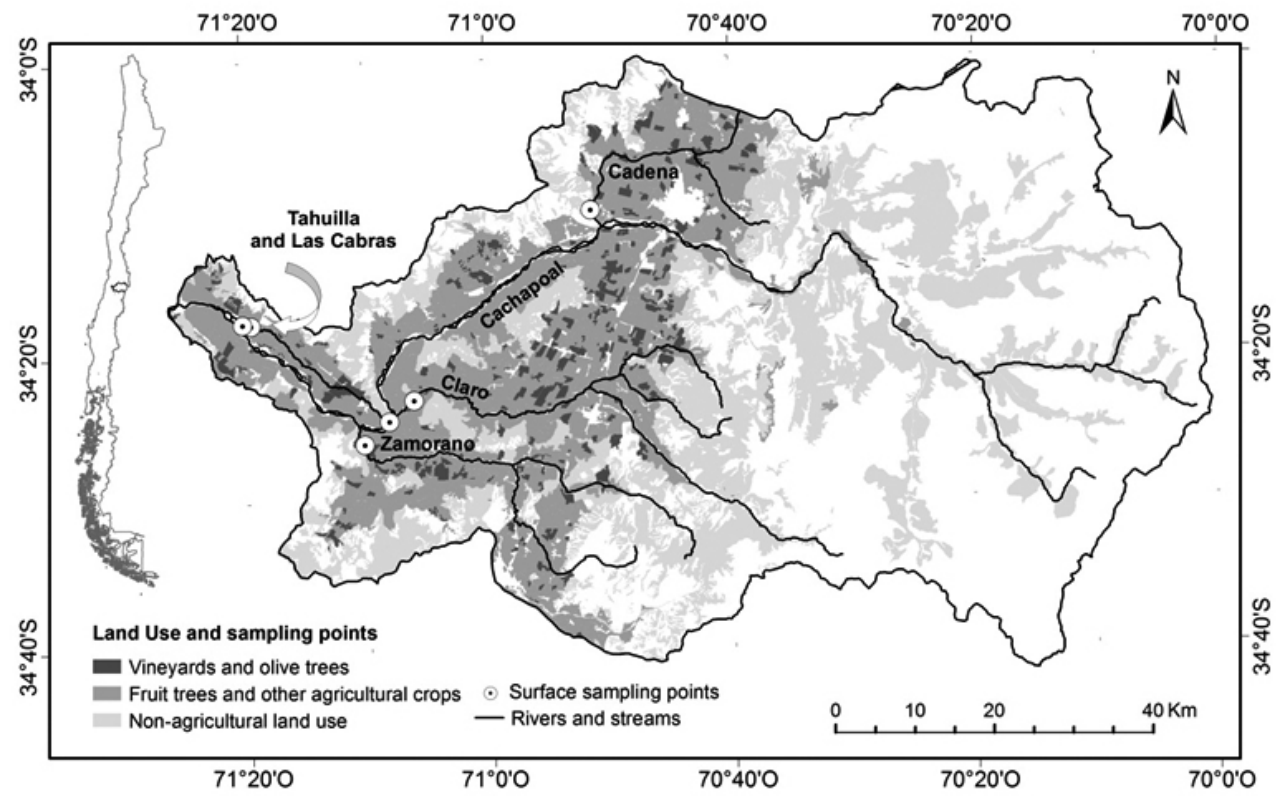

Figure 1: Map of land use of Cachapoal River basin (Central Chile) and surface sampling points. Self-elaboration based on data Fruit Catastro year 2015 [24].

\section{Statistical data analysis}

Intra-group comparisons were carried out to verify differences in the total concentration of pesticides between the collected samples at the end of summer and during the winter season. The statistical $t$ student was used for this purpose and the $\mathrm{p}$ values less than 0.05 were considered significant. The statistical analyses were performed using R software. It is important to mention that for logistical problems, Las Cabras Canal and Cachapoal River were not sampled at both seasons; therefore the statistical analysis was performed for Tahuilla Canal, Cadena Creek, Zamorano Creek and Claro River.

\section{RESULTS AND DISCUSSION}

\section{Optimization of GC-MS chromatographic conditions}

To optimize the GC-MS chromatographic conditions, the individual standards were injected in methanol at a concentration of $1 \mu \mathrm{g} \mathrm{mL}^{-1}$. Each compound was analyzed in scan mode to identify the most abundant ions and retention times. The conditions described by Herrero-Hernández, et al. [21] were initially used, maintaining the carrier gas flow rate at $1.5 \mathrm{~mL} \mathrm{~min}{ }^{-1}$ and using splitless injection mode. However, it was necessary to modify the temperature ramp in order to achieve good peak resolution and separation. The initial conditions were the following: from 100 to $200^{\circ} \mathrm{C}$ at $20^{\circ} \mathrm{C} / \mathrm{min}$ (holding time $1 \mathrm{~min}$ ), to $210^{\circ} \mathrm{C}$ at $1{ }^{\circ} \mathrm{C} / \mathrm{min}$, to $230^{\circ} \mathrm{C}$ at $5^{\circ} \mathrm{C} / \mathrm{min}$, and to $315^{\circ} \mathrm{C}$ at $50^{\circ} \mathrm{C} /$ min $(2.3 \mathrm{~min})$, total chromatographic time of $24 \mathrm{~min}$. In this research, the chromatographic conditions that allowed good separation and quantification of the analytes were the following: electron impact ionization mode, an ionization energy of $70 \mathrm{eV}$, an electron multiplier voltage of $1700 \mathrm{~V}$, a source temperature of $230^{\circ} \mathrm{C}$, a transfer line temperature of $150^{\circ} \mathrm{C}$, helium carrier gas, a flow rate of $1.0 \mathrm{~mL} \mathrm{~min}-1$ and an injection volume of $5 \mu 1$ at $220^{\circ} \mathrm{C}$ in splitless mode. The following temperature gradient was used: from 80 to $180^{\circ} \mathrm{C}$ at $20^{\circ} \mathrm{C} \mathrm{min}^{-1}(2$ minutes), from 180 to $190^{\circ} \mathrm{C}$ at $1^{\circ} \mathrm{C} \mathrm{min}-1$ and from 190 to $310^{\circ} \mathrm{C}$ at $80^{\circ} \mathrm{C} \mathrm{min}{ }^{-1}$ (11.5 minutes). The three most abundant ions of each compound were selected (one to quantify and two to confirm) by comparing the spectra from the mass library (NIST 08) with those obtained when injecting the standards in scan mode. Finally, three different windows were created as a function of retention times in which the selected ions for the compounds included in each window were determined (Table 2).
Optimization of the pre-concentration stage and analytical method validation

To optimize the SPE method, the recovery percentage of each of the compounds was evaluated by modifying the sorbent type, the solvent used for elution and the sample volume. Results obtained for five different types of sorbent tested are shown in Figure $2 \mathrm{a}$ and $2 \mathrm{~b}$. In general, the recovery percentages obtained with $\mathrm{C}_{18}$ and LiChrolut cartridges were similar for most of the compounds, with values that fluctuated between 51 and $91 \%$. The lowest recovery percentages were obtained using the carbon-based sorbent, with the fungicides cyprodinil and pyrimethanil and the insecticide chlorpyrifos presenting the lowest recovery percentage $(<20 \%)$. The best results were obtained using Oasis HLB and Strata X cartridges, with 88 and $69 \%$ of the studied compounds, respectively, presenting a recovery percentage over $60 \%$.

According to these results the Oasis HLB sorbent was selected to evaluate the efficacy of different organic solvents tested and the preconcentrated sample volume. The use of hexane resulted in the worst recovery percentages, which were $<50 \%$ for all of the compounds. When ethyl acetate was used, only eleven compounds presented a recovery percentage over $60 \%$. Meanwhile, when using methanol, acetone or acetonitrile, more than $70 \%$ of the compounds presented good recoveries, with the compound type varying as a function of polarity (Figure $3 \mathrm{a}$ and $3 \mathrm{~b}$ ). Therefore, it was decided to use a sequential elution with acetone and acetonitrile, resulting in recovery values $>70 \%$ for $73 \%$ of the studied compounds. 
Table 2 Optimized parameters GC-MS for the determination of pesticides and some degradation products in water samples.

\begin{tabular}{|c|c|c|c|c|}
\hline & & & \multicolumn{2}{|c|}{ Monitored ions (Abundance) } \\
\hline Compound & RT (min) & $\begin{array}{c}\text { SIM } \\
\text { window }\end{array}$ & $\begin{array}{c}\text { Quantification } \\
\text { ion } \mathbf{( m / \mathbf { z } )}\end{array}$ & Identification ions (m/z) \\
\hline Fluometuron & 4.8 & 1 & 174 & $219(794) / 187(536)$ \\
\hline CGA 92370 & 7.5 & 1 & 148 & $120(572) / 91(322)$ \\
\hline DIA & 8.0 & 1 & 173 & $158(870) / 145(751)$ \\
\hline DEA & 8.2 & 1 & 172 & $187(349) / 174(309)$ \\
\hline DET & 8.6 & 1 & 186 & $188(319) / 83(287)$ \\
\hline Simazine & 9.9 & 2 & 201 & $44(798) / 186(565)$ \\
\hline Atrazine & 10.2 & 2 & 200 & $215(615) / 58(378)$ \\
\hline Diazoxon & 10.6 & 2 & 273 & $137(740) / 288(319)$ \\
\hline Terbuthylazine & 10.8 & 2 & 214 & $43(574) / 173(512)$ \\
\hline Diazinon & 11.2 & 2 & 137 & $152(659) / 179(569)$ \\
\hline Pyrimethanil & 11.4 & 2 & 198 & 199 \\
\hline Acetochloro & 13.9 & 3 & 59 & $146(839) / 162(696)$ \\
\hline Metalaxyl & 15.1 & 3 & 45 & $206(326) / 132(299)$ \\
\hline Chlorpyrifos & 17.7 & 3 & 197 & $199(974) / 314(865)$ \\
\hline Cyprodinil & 20.8 & 3 & 224 & $225(616) / 210(100)$ \\
\hline Kresoxim-methyl & 26.7 & 3 & 116 & $131(533) / 206(516)$ \\
\hline
\end{tabular}
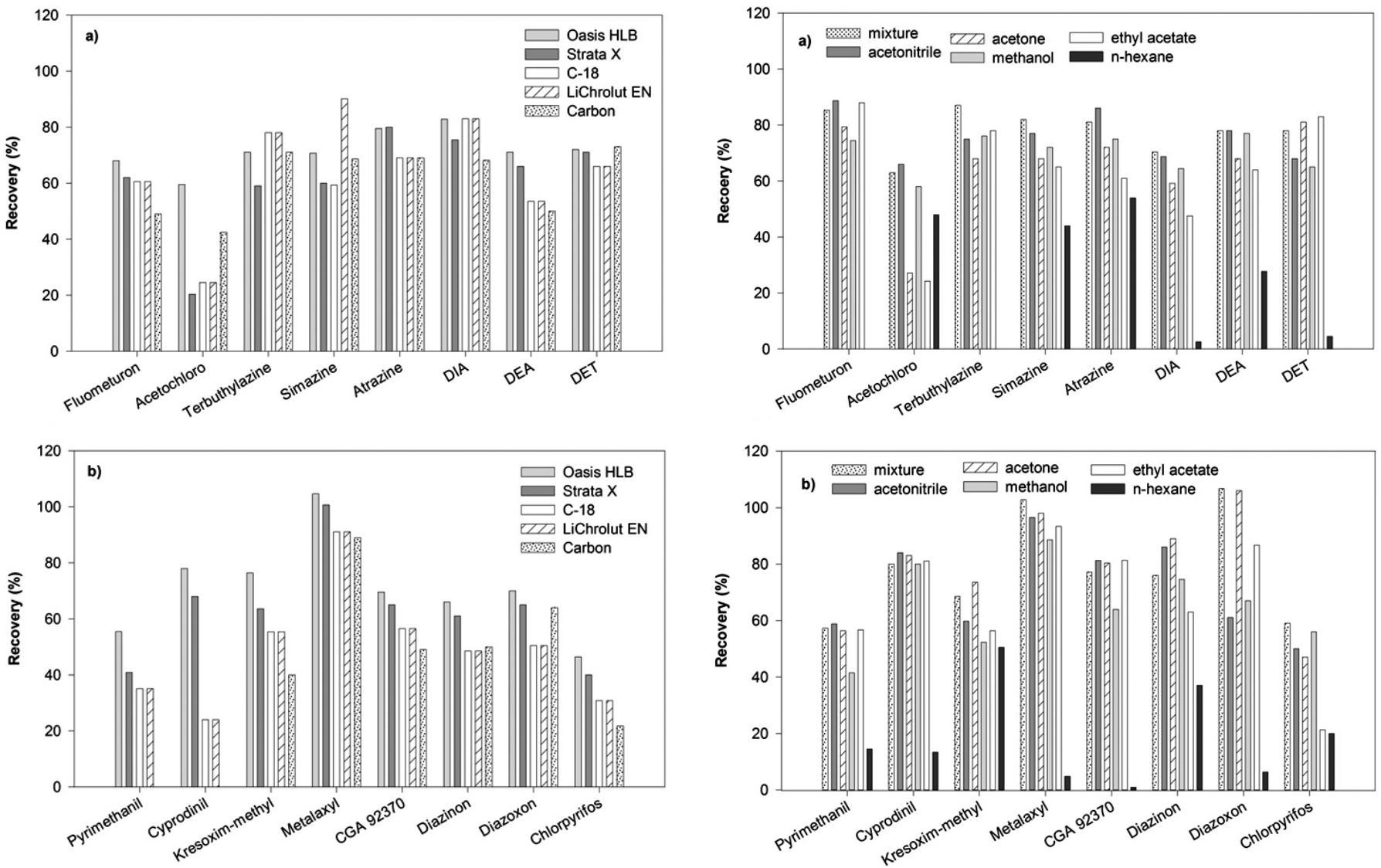

Figure 2: Recoveries of pesticides after solid phase extraction with different sorbents (a and b). In all cases, $100 \mathrm{~mL}$ of UHQ water are preconcentrated with all compounds at $1.0 \mu \mathrm{g} \mathrm{L}-1$ and eluted with $8 \mathrm{~mL}$ of methanol.

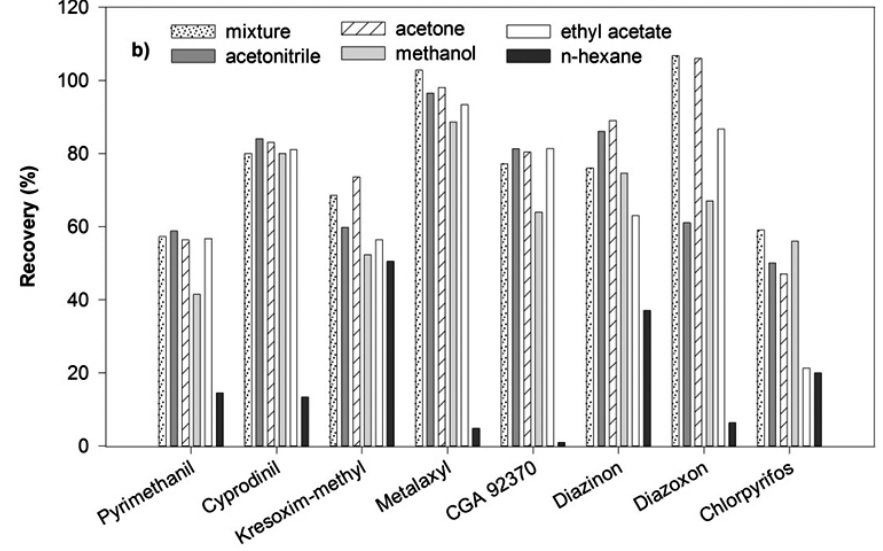

Figure 3: Recoveries of pesticides after solid phase extraction with different solvents using Oasis HLB catridges (a and b). In all cases, $100 \mathrm{~mL}$ of UHQ water are preconcentrated with all compounds at $1.0 \mu \mathrm{g} \mathrm{L}-1$ and eluted with $8 \mathrm{~mL}$ of methanol. 
Another of the studied parameters was pre-concentrated sample volume, for which 50,100, 250, 500 and $1000 \mathrm{~mL}$ of UHQ water spiked with $0.2 \mu \mathrm{g}$ of each compound were passed through Oasis HLB cartridges. The results showed that the recovery percentage remains constant when pre-concentrating between 50 and $500 \mathrm{~mL}$ of water, and decreases considerably when pre-concentrating a greater sample volume. Considering this variation and the time required to preconcentrate the various volumes of water, it was decided to work with a volume of water of $500 \mathrm{~mL}$ since it allows a greater recovery percentage to be obtained.

To evaluate the matrix effect, the analyte signals were compared in duplicate at a concentration of $0.1 \mu \mathrm{g} \mathrm{L}^{-1}$ by pre-concentrating $500 \mathrm{~mL}$ of UHQ water and river water. Most of the compounds presented a signal suppression or enhancement between 5 and 19\%, with the exception of the degradation products CGA-92370, DEA, DET and diazoxon, which presented a variation $>25 \%$. Therefore, to minimize the matrix effect and avoid a decrease in or overestimation of the pesticide concentration, matrix-matched standards were used.

Table 3: Quality control parameters of SPE-GC-MS method, applied for analysis of pesticides and degradation products in water samples.

\begin{tabular}{|c|c|c|c|c|c|c|c|c|}
\hline Compound & Regression equation & $\begin{array}{c}\mathrm{r}^{2} \\
(0.10-1.50 \\
\left.\mu \mathrm{g} \mathrm{L}^{-1}\right)\end{array}$ & $\begin{array}{c}\text { LOD } \\
\left(\mu \mathrm{g} \mathrm{L}^{-1}\right)\end{array}$ & $\begin{array}{c}\text { LOQ } \\
\left(\mu \mathrm{g} \mathrm{L}^{-1}\right)\end{array}$ & $\begin{array}{l}\mathrm{CV}(\%) \\
\text { interday }\end{array}$ & $\begin{array}{l}\mathrm{CV}(\%) \\
\text { intraday }\end{array}$ & $\begin{array}{c}\text { Recovery } \\
(\%)\end{array}$ & $\operatorname{RSD}(\%)$ \\
\hline Fluometuron & $y=190985 x+5702$ & 0.9991 & 0.029 & 0.096 & 10 & 10 & 89.5 & 6.4 \\
\hline CGA 92370 & $y=1 * 10^{6} x-42019$ & 0.9992 & 0.025 & 0.084 & 7 & 7 & 77.5 & 0.7 \\
\hline DIA & $y=1 * 10^{6} x+703880$ & 0.9928 & 0.025 & 0.085 & 8 & 18 & 75.5 & 7.8 \\
\hline DEA & $y=9 * 10^{6} x+703723$ & 0.9985 & 0.024 & 0.080 & 4 & 8 & 81.5 & 4.9 \\
\hline DET & $y=1 * 10^{7} x+1 * 10^{6}$ & 0.9985 & 0.016 & 0.054 & 8 & 10 & 88.5 & 14.8 \\
\hline Simazine & $y=3^{*} 10^{6} x+581544$ & 0.9989 & 0.021 & 0.069 & 16 & 9 & 74.3 & 6.7 \\
\hline Atrazine & $y=8 * 10^{6} x+662734$ & 0.9991 & 0.028 & 0.092 & 5 & 11 & 75.0 & 8.5 \\
\hline Diazoxon & $y=828297 x+14721$ & 0.9994 & 0.011 & 0.036 & 16 & 8 & 105.0 & 2.8 \\
\hline Terbuthylazine & $y=1 * 10^{6} x+184335$ & 0.9964 & 0.027 & 0.091 & 12 & 18 & 84.0 & 4.2 \\
\hline Diazinon & $y=802794 x+264370$ & 0.9967 & 0.025 & 0.082 & 14 & 12 & 79.0 & 4.2 \\
\hline Pyrimethanil & $y=3 * 10^{6} x-90210$ & 0.9997 & 0.026 & 0.088 & 7 & 9 & 61.0 & 5.7 \\
\hline Acetochloro & $y=491847 x-14371$ & 0.9997 & 0.030 & 0.099 & 15 & 11 & 72.5 & 13.4 \\
\hline Metalaxyl & $y=809862 x-15016$ & 0.9994 & 0.029 & 0.097 & 3 & 8 & 105.5 & 3.5 \\
\hline Chlorpyrifos & $y=182429 x-9334$ & 0.9992 & 0.025 & 0.084 & 13 & 19 & 58.0 & 1.4 \\
\hline Cyprodinil & $y=1 * 10^{6} x-21427$ & 0.9989 & 0.019 & 0.063 & 6 & 9 & 87.0 & 9.9 \\
\hline Kresoxim-methyl & $y=845199 x-4658$ & 0.9999 & 0.027 & 0.090 & 12 & 14 & 80.0 & 15.6 \\
\hline
\end{tabular}

\section{Pesticide determination in real surface water samples}

The method was applied to the determination of the studied compounds in different samples of surface water from the Cachapoal River in Central Chile. A percentage $>87 \%$ of pesticides included in this work were detected in one or more of the sampled sites. Of the sixteen studied analytes, atrazine, DET, pyrimethanil, cyprodinil and diazinon were detected in most surface water samples, while fluometuron, acetochlor and CGA 92370 were not detected in any of the analyzed samples. At the end of the summer, pyrimethanil and cyprodinil were the analytes detected in the greatest concentrations, while in winter season, simazine and DET presented the highest concentrations (Table 4). Figure 4a shows that at the end of the summer, DET, pyrimethanil, cyprodinil and chlorpyrifos were detected in more than $15 \%$ of the samples in concentrations above the maximum individual limit established by the EC $(0.1$ $\left.\mu \mathrm{g} \mathrm{L}^{-1}\right)$. Regarding the concentrations of compounds detected in samples at winter period terbuthylazine, atrazine, DIA, DET and diazinon, were detected in more than $40 \%$ of the analyzed samples at concentrations over $0.1 \mu \mathrm{g} \mathrm{L}^{-1}$ (Figure 4b). Of all of the sampled sites at the end of the summer, Las Cabras Canal presented the greatest level of pesticide contamination and of the samples collected in winter season, Tahuilla Canal presented the greatest total pesticide concentration. Finally, statistical analysis using the t student showed significant differences in the total concentration of pesticides for the sampled sites at the end of the summer and winter season (Table 5).

It is important to stress that in this work the monitored irrigation canals
The linearity parameters, LODs and LOQs, were determined by preparing a calibration curve between $0.1-1.5 \mu \mathrm{g} \mathrm{L}^{-1}$ for each compound in $500 \mathrm{~mL}$ of river water treated in the same way as the samples. Good linearity was obtained for all the samples, with correlation coefficients $>0.99$ and limits of quantification lower than the maximum established by the EC. The LOD fluctuated between 0.011 and $0.030 \mu \mathrm{g} \mathrm{L}^{-1}$ for diazoxon and acetochlor, respectively, and the LOQ between 0.036 and $0.099 \mu \mathrm{g} \mathrm{L}^{-1}$ for the same compounds. Both parameters were estimated as 3 and 10 times the signal/noise relationship for each analyte, respectively (Table 3 ).

The precision of the method (repeatability and reproducibility) was evaluated by determining the relative standard deviation of the peak area in five water samples fortified with $0.1 \mu \mathrm{g} \mathrm{L}^{-1}$ of each compound. In every case, the pesticide and degradation product signal presented a coefficient of variation $<19 \%$. The accuracy of the method was determined by evaluating the recovery percentage by modifying the type of sorbent and elution solvent and the sample volume that passed through the cartridge. The recovery percentages varied between 61 and $107 \%$, with a coefficient of variation between 3 and $18 \%$. 
J. Chil. Chem. Soc., 63, № 2 (2018)

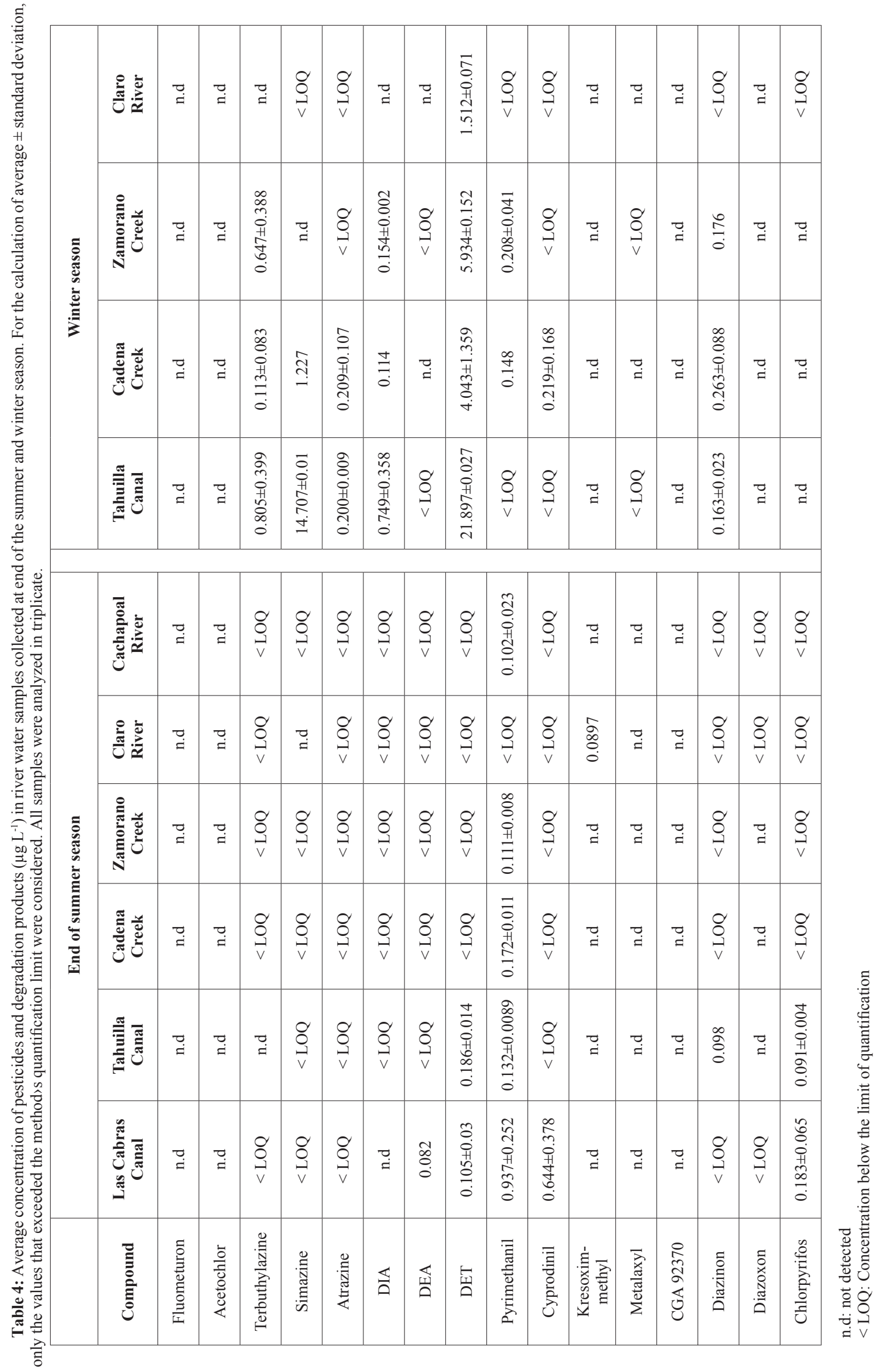



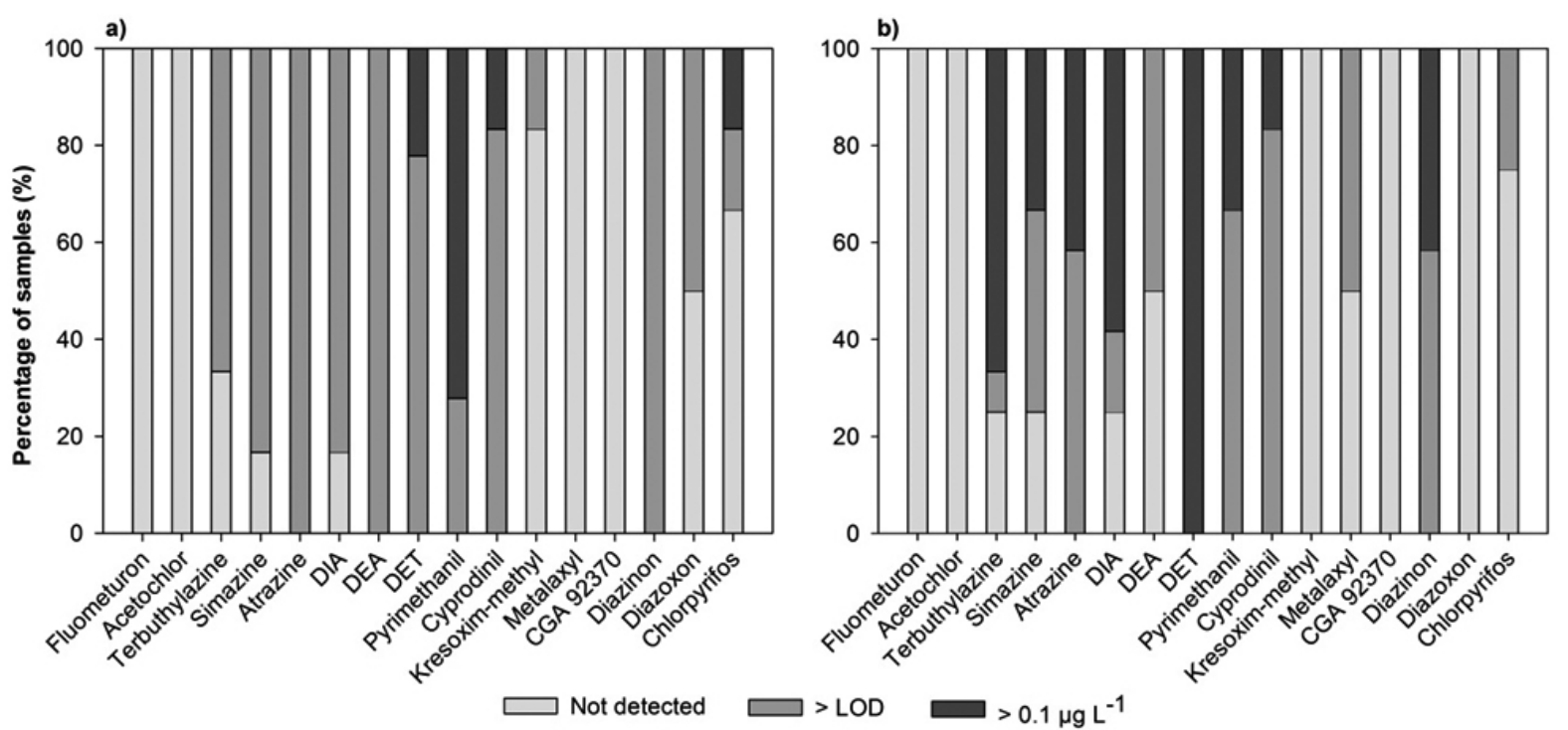

Figure 4: Distribution of samples collected at the end of the summer season (a) and at the winter season (b) according to the percentages of samples with not detected compounds, or with concentrations higher than LODs and above $0.1 \mu \mathrm{g} \mathrm{L}^{-1}$.

Table 5: Total concentration of pesticides $\left(\mu \mathrm{g} \mathrm{L}^{-1}\right)$ and statistic analysis (t-student-test) by sites/season samples. For the statistical analysis, the concentrations lower than limit of quantification were considered as zero.

\begin{tabular}{|c|c|c|c|}
\hline \multicolumn{4}{|c|}{ Pesticides total concentration } \\
\hline Site & Summer season & Winter season & t-student-test \\
\hline Tahuilla Canal & $0.412 \pm 0.155$ & $38.467 \pm 0.839$ & $\mathrm{p}<0.001$ \\
\hline Cadena Creek & $0.172 \pm 0.011$ & $5.151 \pm 1.699$ & $\mathrm{p}<0.037$ \\
\hline Zamorano Creek & $0.111 \pm 0.007$ & $7.002 \pm 0.492$ & $\mathrm{p}<0.002$ \\
\hline Claro River & $0.030 \pm 0.052$ & $1.512 \pm 0.070$ & $\mathrm{p}<0.001$ \\
\hline
\end{tabular}

The degradation products DEA and DET were detected in all of the samples analyzed at the end of summer, although also in concentrations that did not surpass the limits of quantification. In the winter period, $75 \%$ of the samples presented a triazine-derived degradation product, with DET exhibiting the greatest concentration, with a maximum of $21.897 \mu \mathrm{g} \mathrm{L}^{-1}$ in the Tahuilla Canal. In general, the sites sampled in winter presented a higher concentration of herbicides and degradation products derived from triazine than the sites sampled in summer, surpassing the individual limits $\left(0.1 \mu \mathrm{g} \mathrm{L}^{-1}\right)$ for human consumption established by EC. This increase can be explained by the fact that some pesticides whose formulation contains simazine, terbuthylazine and/ or atrazine are applied during the autumn or winter, coinciding with the date of the winter period sampling. These results are consistent with those reported by Dores, et al. [25], which showed that in the Primavera do Leste region, Mato Grosso (central-western Brazil), there is an increase in the percentage of pesticides detected in bodies of surface water during the rainy seasons, with atrazine, simazine and DEA detected at the greatest concentrations. Likewise, studies carried out in Europe [22] show that atrazine, simazine, terbuthylazine and their degradation products are the most frequently detected compounds in surface water in areas with intense agricultural activity.

\section{Occurrence of fungicides in surface water of Cachapoal river basin}

Unlike with pesticides, there is little research that accounts for the presence of fungicides in bodies of surface water in agricultural zones. However, studies carried out in Portugal, France, Germany, Australia and the United States have detected residues of pyrimethanil, carbendazim, metalaxyl, propiconazole, myclobutanil and tebuconazole in rivers and groundwater of basins with intense agricultural activity [26]. In Spain, these substances have been detected in the soil and sediments in wine-growing areas [27], as well as in bodies of surface water in various times of the year [28].
In the present work, the most ubiquitous fungicides were pyrimethanil and cyprodinil, which were detected in all of the samples, reaching maximum concentrations of $0.937 \mu \mathrm{g} \mathrm{L}^{-1}$ and $0.644 \mu \mathrm{g} \mathrm{L}{ }^{-1}$, respectively. These results are much less than those reported by Gregoire, et al. [29], who evaluated the presence of seventeen pesticides over four years in a wine-growing catchment in France, detecting residues of pyrimethanil in all of the surface water samples collected in 2005 , with a maximum concentration of $1.8 \mu \mathrm{g} \mathrm{L}^{-1}$. Similarly, Wightwick, et al. [30] reported the presence of fungicides in surface water of a catchment with intense horticultural activity in southeastern Australia, finding pyrimethanil in $16 \%$ of the analyzed samples; however, in no case was cyprodinil detected. Herrero-Hernández, et al. [28] detected both compounds in three sites in La Rioja (Spain) over a year of sampling. The results show that, while they were not the most ubiquitous compounds, both were detected at a concentration above $0.1 \mu \mathrm{g} \mathrm{L}^{-1}$, with pyrimethanil reaching a maximum of $0.590 \mu \mathrm{g} \mathrm{L}^{-1}$ in September 2010 and cyprodinil a maximum of $0.981 \mu \mathrm{g} \mathrm{L}^{-1}$ in September 2011.

Of all the studied sites in this work, Las Cabras Canal presented the greatest level of fungicide contamination at the end of the summer period and La Cadena Creek the greatest concentration in winter. In general, the total fungicide concentration was higher in the sites sampled at the end of summer, with ranges between 0.090 and $1.580 \mu \mathrm{g} \mathrm{L}^{-1}$. This could be because spring and summer make up the main vegetable growing season, which is the period of greatest fungicide use. In addition, in vineyards it is common to apply fungicides as aerosol as a preventive measure; therefore, these substances can reach bodies of water through drift during the crop growing season, coinciding with the sampling period at the end of summer.

Occurrence of insecticides in surface water of Cachapoal River basin

Of the insecticides assessed in this work, diazinon, which was detected in all of the analyzed samples, was the most ubiquitous. This compound presented a greater concentration in the winter period, while in the summer period concentrations did not surpass the limit of quantification of the method (except Tahuilla Canal). Chlorpyrifos was detected in only $30 \%$ of the analyzed samples, with a maximum concentration of $0.183 \mu \mathrm{g} \mathrm{L}^{-1}$ at the end of the summer. In general, the total insecticide concentration was similar in both sampling periods, which could be due to the heterogeneity of the crops in the basin, variation in the local topography and the physiochemical characteristics of the studied compounds. For example, the pesticides with elevated water solubility and a low tendency to be adsorbed in soil particles $(300<\mathrm{Koc}<500)$ have a greater potential for movement to bodies of water through leaching or surface runoff than those that are less soluble or highly sorbed to soil (Koc > 500) [5]. In this sense, although diazinon presents a Koc similar to chlorpyrifos, its water solubility is sixty times greater, allowing this insecticide to enter bodies of water mostly in the dissolved phase in the winter period.

Unlike herbicides and fungicides, insecticides are usually present for a short 
time period in agriculture-affected surface water, making it crucial to perform monitoring with greater frequency in order to detect these substances. In spite of this limitation, studies have documented the presence of organochlorine carbamate and organophosphate insecticides in Mediterranean bodies of water, noting that these compounds are generally found in low concentrations (ng $\mathrm{L}^{-1}$ ) or detected infrequently $[8,31]$. Finally, it is important to stress that the presence of insecticides in bodies of water constitutes a high risk to the biodiversity of these ecosystems, given that it has been demonstrated that elevated toxicity can have adverse effects on aquatic invertebrates in a short time period [32-33].

\section{CONCLUSIONS}

The multi-residue method based on SPE -GC-MS was used to determine eleven pesticides and five degradation products in thirty surface water samples from Cachapoal River basin, Central Chile. The best results were obtained pre-concentrating $500 \mathrm{~mL}$ of water with Oasis HLB cartridges, and using a sequential elution with $4 \mathrm{~mL}$ of acetone and $4 \mathrm{~mL}$ of acetonitrile. The compounds DET, pyrimethanil, cyprodinil and diazinon were detected in most surface water samples, with simazine and degradation product DET the compounds that were present at the greatest concentrations. An increase in total pesticide concentration was observed in winter period compared to the concentration at the end of the summer, with significant differences in Tahuilla Canal, Cadena Creek, Zamorano Creek and Claro River. The obtained results demonstrate the vulnerability of water resources to pesticide contamination and the need to carry out broader monitoring programs to study the presence of these substances as well as their degradation products in surface water of this area of Chile and propose different corrective measures as needed.

\section{ACKNOWLEDGMENT}

This work was partly funded by the Government of Spain (MINECO/ FEDER UE) as part of Project AGL2015-69485-R. María José Climent thanks the National Commission for Scientific and Technological Research (CONICYT 21150573) for the financing used to carry out this work at the Institute of Natural Resources and Agrobiology of Salamanca (Spain) Dr. Urrutia thanks the Water Research Center for Agriculture and Mining (CRHIAM/CONICYT/FONDAP/15130015).

\section{REFERENCES}

1. Zhang, Y. Q.; Johnson, A. C.; Su, C.; Zhang, M.; Jurgens, M. D.; Shi, Y. J.; Lu, Y. L., Which persistent organic pollutants in the rivers of the Bohai Region of China represent the greatest risk to the local ecosystem? Chemosphere. 178, 11-18, (2017).

2. Xiao, P. F.; Liu, F. G.; Liu, Y. H.; Yao, S. M.; Zhu, G. N., Effects of Pesticide Mixtures on Zooplankton Assemblages in Aquatic Microcosms Simulating Rice Paddy Fields. Bulletin of environmental contamination and toxicology. 99, 1, 27-32, (2017).

3. Coscolla, C.; Lopez, A.; Yahyaoui, A.; Colin, P.; Robin, C.; Poinsignon, Q.; Yusa, V., Human exposure and risk assessment to airborne pesticides in a rural French community. Sci. Total Environ., 584, 856-868, (2017).

4. Arias-Estévez, M.; López-Periago, E.; Martínez-Carballo, E.; SimalGándara, J.; Mejuto, J.-C.; García-Río, L., The mobility and degradation of pesticides in soils and the pollution of groundwater resources. Agriculture, Ecosystems \& Environment. 123, 4, 247-260, (2008).

5. Gavrilescu, M., Fate of Pesticides in the Environment and its Bioremediation. Engineering in Life Sciences. 5, 6, 497-526, (2005).

6. Qian, Y.; Matsumoto, H.; Liu, X. Y.; Li, S. Y.; Liang, X.; Liu, Y. N.; Zhu, G. N.; Wang, M. C., Dissipation, occurrence and risk assessment of a phenyturea herbicide tebuthiuron in sugarcane and aquatic ecosystems in South China. Environ. Pollut., 227, 389-396, (2017).

7. Rousis, N. I.; Bade, R.; Bijlsma, L.; Zuccato, E.; Sancho, J. V.; Hernandez, F.; Castiglioni, S., Monitoring a large number of pesticides and transformation products in water samples from Spain and Italy. Environ Res., 156, 31-38, (2017).

8. Herrero-Hernández, E.; Rodríguez-Cruz, M. S.; Pose-Juan, E.; SánchezGonzález, S.; Andrades, M. S.; Sánchez-Martín, M. J., Seasonal distribution of herbicide and insecticide residues in the water resources of the vineyard region of La Rioja (Spain). Sci. Total Environ., 609, 161-171, (2017)

9. Stayner, L. T.; Almberg, K.; Jones, R.; Graber, J.; Pedersen, M.; Turyk, M., Atrazine and nitrate in drinking water and the risk of preterm delivery and low birth weight in four Midwestern states. Environ. Res., 152, 294 303, (2017).

10. Union, E., Directive 2008/105/EC of the European Parliament and of the Council of 16 December 2008 on environmental quality standards in the field of water policy, amending and subsequently repealing Council Directives 82/176/EEC, 83/513/EEC, 84/156/EEC, 84/491/EEC, 86/280/ EEC and amending Directive 2000/60/EC of the European Parliament and of the Council. In Official Journal of the European Union, Union, E., Ed. 2008; Vol. 51, pp 84-97.

11. Bach, M.; Diesner, M.; Grossmann, D.; Guerniche, D.; Hommen, U.; Klein, M.; Kubiak, R.; Muller, A.; Preuss, T. G.; Priegnitz, J.; Reichenberger, S.; Thomas, K.; Trapp, M., Pesticide exposure assessment for surface waters in the EU. Part 2: Determination of statistically based run-off and drainage scenarios for Germany. Pest Management Science. 73, 5, 852-861, (2017).

12. Ferreira, A. d. S. G.; da Silva, H. C. M. P.; Rodrigues, H. O. S.; Silva, M.; de Albuquerque Junior, E. C., Occurrence and spatial-temporal distribution of herbicide residues in the Ipojuca River sub-basin, Pernambuco, Brazil. Revista Brasileira De Engenharia Agricola E Ambiental. 20, 12, 1124 1128, (2016).

13. De Geronimo, E.; Aparicio, V. C.; Barbaro, S.; Portocarrero, R.; Jaime, S.; Costa, J. L., Presence of pesticides in surface water from four sub-basins in Argentina. Chemosphere. 107, 423-431, (2014).

14. Retamal, M.; Costa, C.; Suarez, J. M.; Richter, P., Multi-determination of organic pollutants in water by gas chromatography coupled to triple quadrupole mass spectrometry. Int. J. Environ. Anal. Chem., 93, 1, 93-107, (2013).

15. Montory, M.; Ferrer, J.; Rivera, D.; Villouta, M. V.; Grimalt, J. O., First report on organochlorine pesticides in water in a highly productive agroindustrial basin of the Central Valley, Chile. Chemosphere. 174, 148-156, (2017).

16. Normalización, I. N. d., Norma Chilena de Agua Potable, Parte 1: Requisitos. NCh 409/1. Of 1984. Normalización, I. N. d., Ed. 1984; pp $1-11$.

17. Buszewski, B.; Szultka, M., Past, Present, and Future of Solid Phase Extraction: A Review. Crit. Rev. Anal. Chem., 42, 3, 198-213, (2012).

18. Tankiewicz, M.; Fenik, J.; Biziuk, M., Solventless and solvent-minimized sample preparation techniques for determining currently used pesticides in water samples: A review. Talanta. 86, 8-22, (2011).

19. Bonansea, R. I.; Ame, M. V.; Wunderlin, D. A., Determination of priority pesticides in water samples combining SPE and SPME coupled to GC-MS A case study: Suquia River basin (Argentina). Chemosphere. 90, 6, 1860$1869,(2013)$

20. Ganadero, S. A. y., Informe de Venta de Plaguicidas de Uso Agrícola en Chile. Servicio Agrícola y Ganadero, D. P. A. y. F., Subdepartamento de Viñas y Vinos, Inocuidad y Biotecnología, Sección Inocuidad., Ed. Servicio Agrícola y Ganadero: 2012; pp 1-113.

21. Herrero-Hernández, E.; Pose-Juan, E.; Álvarez-Martín, A.; Andrades, M. S.; Rodríguez-Cruz, M. S.; Sánchez-Martín, M. J., Pesticides and degradation products in groundwaters from a vineyard region: Optimization of a multiresidue method based on SPE and GC-MS. J. Sep. Sci., 35, 24, 3492-3500, (2012).

22. Herrero-Hernandez, E; Andrades, M. S; Alvarez-Martin, A; PoseJuan, E.; Rodriguez-Cruz, M. S.; Sanchez-Martin, M. J., Occurrence of pesticides and some of their degradation products in waters in a Spanish wine region. J. Hydrol., 486, 234-245, (2013).

23. Lewis, K. A.; Tzilivakis, J.; Warner, D. J.; Green, A., An international database for pesticide risk assessments and management. Human and Ecological Risk Assessment: An International Journal. 22, 4, 1050-1064, (2016).

24. CIREN, Catastro Frutícola. Principales Resultados, Región del Libertador General Bernardo O’Higgins, Julio 2015. Oficina de Estudios y Políticas Agrarias, O. C. d. I. d. R. N., CIREN. Chile, Ed. 2015.

25. Dores, E.; Carbo, L.; Ribeiro, M.; M De-Lamonica-Freire, E., Pesticide Levels in Ground and Surface Waters of Primavera do Leste Region, Mato Grosso, Brazil. 2008; Vol. 46, p 585-90.

26. Reilly, T. J.; Smalling, K. L.; Orlando, J. L.; Kuivila, K. M., Occurrence of boscalid and other selected fungicides in surface water and groundwater in three targeted use areas in the United States. Chemosphere. 89, 3, 228-234, (2012).

27. Pose-Juan, E.; Sánchez-Martín, M. J.; Andrades, M. S.; RodríguezCruz, M. S.; Herrero-Hernández, E., Pesticide residues in vineyard soils from Spain: Spatial and temporal distributions. Sci. Total Environ., 514, Supplement C, 351-358, (2015). 
28. Herrero-Hernández, E.; Pose-Juan, E.; Sánchez-Martín, M. J.; Andrades, M. S.; Rodríguez-Cruz, M. S., Intra-annual trends of fungicide residues in waters from vineyard areas in La Rioja region of northern Spain. Environ. Sci. Pollut. Res., 23, 22, 22924-22936, (2016).

29. Gregoire, C.; Payraudeau, S.; Domange, N., Use and fate of 17 pesticides applied on a vineyard catchment. Int. J. Environ. Anal. Chem., 90, 3-6, 406-420, (2010)

30. Wightwick, A. M.; Bui, A. D.; Zhang, P.; Rose, G.; Allinson, M.; Myers, J. H.; Reichman, S. M.; Menzies, N. W.; Pettigrove, V.; Allinson, G., Environmental Fate of Fungicides in Surface Waters of a HorticulturalProduction Catchment in Southeastern Australia. Arch. Environ. Contam. Toxicol., 62, 3, 380-390, (2012).
31. Cruzeiro, C.; Pardal, M. Â.; Rocha, E.; Rocha, M. J., Occurrence and seasonal loads of pesticides in surface water and suspended particulate matter from a wetland of worldwide interest - the Ria Formosa Lagoon, Portugal. Environ. Monit. Assess., 187, 11, 669, (2015).

32. Papadakis, E.-N.; Tsaboula, A.; Kotopoulou, A.; Kintzikoglou, K.; Vryzas, Z.; Papadopoulou-Mourkidou, E., Pesticides in the surface waters of Lake Vistonis Basin, Greece: Occurrence and environmental risk assessment. Sci. Total Environ., 536, Supplement C, 793-802, (2015).

33. Ippolito, A.; Kattwinkel, M.; Rasmussen, J. J.; Schäfer, R. B.; Fornaroli, R.; Liess, M., Modeling global distribution of agricultural insecticides in surface waters. Environ. Pollut., 198, Supplement C, 54-60, (2015). 